\title{
The Antimicrobial Activity of Extracts of the Lichen Hypogymnia tubulosa and Its 3-Hydroxyphysodic Acid Constituent
}

\author{
Meral Yılmaz ${ }^{\mathrm{a}}$, Turgay Tay ${ }^{\mathrm{b}}$, Merih Kıvanç, ${ }^{\mathrm{a}, *}$, Hayrettin Türk \\ and Ayşen Özdemir Türk ${ }^{a}$ \\ a Anadolu University, Department of Biology, 26470 Eskisehir, Turkey. \\ Fax: +90 222320 4910. E-mail: mkivanc@anadolu.edu.tr \\ b Anadolu University, Department of Chemistry, 26470 Eskişehir, Turkey \\ * Author for correspondence and reprint requests \\ Z. Naturforsch. 60 c, 35-38 (2005); received October 11, 2004
}

The antimicrobial activity and the MIC values of the diethyl ether, acetone, chloroform, petroleum ether, and ethanol extracts of the lichen Hypogymnia tubulosa and its 3-hydroxyphysodic acid constituent have been investigated against some microorganisms. At least one of the extracts or 3-hydroxyphysodic acid showed antimicrobial activity against Aeromonas hydrophila, Bacillus cereus, Bacillus subtilis, Escherichia coli, Klebsiella pneumoniae, Listeria monocytogenes, Proteus vulgaris, Salmonella typhimurium, Staphylococcus aureus, Streptococcus faecalis, and Candida albicans. No antifungal activity of the extracts has been observed against ten filamentous fungi.

Key words: Hypogymnia tubulosa, 3-Hydroxyphysodic Acid, Antimicrobial Activity

\section{Introduction}

Although about $8 \%$ of the terrestrial ecosystems consist of lichens and more than 20000 lichen species are distributed throughout the world, their biological activities and biological active compounds remain unexplored in great extent (Toma et al., 2001). Lichens produce a wide range of unique secondary metabolites and remarkable biological activities of some have attracted the interest of many researchers. A limited number of investigations have proved that some lichens and lichen compounds show antibacterial, antifungal, antiproliferative, antiviral, anti-inflammatory, antiprotozoal, analgesic, antipyretic, and anti-tumour activities. Lists of the antibacterial and antifungal activities of lichen compounds and lichens against bacteria and fungi can be found in a review and a book (Huneck, 1999, 2001).

This paper presents the results of antibacterial activity tests of five extracts of the lichen Hypogymnia tubulosa and its 3-hydroxyphysodic acid constituent (Fig. 1). To the best of our knowledge no information about the antibacterial activities of the lichen Hypogymnia tubulosa and 3-hydroxyphysodic acid is available for the last decade from literature.

\section{Experimental}

\section{Microorganisms}

Staphylococcus aureus (ATCC 6538), Escherichia coli (ATCC 25922), Pseudomonas aeruginosa (ATCC 27853), Aspergillus niger sp. (ATCC 9807), and Fusarium solani (ATCC 12820) (from American Type Culture Collection, USA), Proteus vulgaris (NRRL B-123), Bacillus cereus (NRRL B-3711), Bacillus subtilis (NRRL B-744), Streptococcus faecalis (NRRL B-14617), and Geotricum condidum (NRRL Y-552) (from Northern Regional Research Laboratory of the USDA, Peoria, Illinois, USA), Listeria monocytogenes (from Ankara University, Faculty of Agriculture, Ankara, Turkey), Yersinia enterocolitica and Aeromonas hydrophila (from Ankara University, Faculty of Veterinary, Ankara, Turkey), Pseudomonas syringae pv. tomato (TPPB 4212), Fusarium moniliforme, Fusarium oxyporum, and Fusarium culmorum (from Agriculture Research Center, Eskişehir, Turkey), Candida albicans, Candida glabrata, Mucor, and Aspergillus fumigatus (from Osmangazi University, Faculty of Medicine, Eskişehir, Turkey), Penicillum parasiticus (from Trakya University, Department of Biology, Edirne, Turkey), Klebsiella pneumoniae, Cladosporium sp., and Salmonella typhimurium (available in our department) were used as microorganisms. Bacteria 
and yeasts were kept on nutrient agar and yeast extract agar plates at $4{ }^{\circ} \mathrm{C}$, respectively. Fungal test cultures were subcultured on potato dextrose agar (PDA) for $5-7 \mathrm{~d}$ at $25^{\circ} \mathrm{C}$.

\section{Lichen material}

Hypogymnia tubulosa (Schaer.) Havaas was collected in Büyükyayla, Eskişehir Province, Turkey at $1200 \mathrm{~m}$ on November 29, 2003. A voucher is stored at the Herbarium of Anadolu University in the Department of Biology (ANES).

\section{Extraction}

For extraction, $5 \mathrm{~g}$ air-dried and ground lichen samples were added to $100 \mathrm{ml}$ of diethyl ether, acetone, petroleum ether, and ethanol. For chloroform extraction, a $10 \mathrm{~g}$ lichen sample and $150 \mathrm{ml}$ chloroform were used. The mixtures were first sonicated for $30 \mathrm{~min}$, then left at room temperature overnight and filtered. The amounts of the extract residues determined after removal of the solvents of the filtrates with a rotary evaporator were $60 \mathrm{mg}$ for the ethanol extract, $26 \mathrm{mg}$ for the diethyl ether extract, $42 \mathrm{mg}$ for the acetone extract, $6 \mathrm{mg}$ for the petroleum ether extract, and $74 \mathrm{mg}$ for the chloroform extract.

\section{Determination of MIC values of the extracts}

The Kirby and Bauer disk diffusion method (National Committee for Clinical Laboratory Standards, 1993) has been used to determine MIC values of the extracts of the lichen Hypogymnia tubulosa against test bacteria and fungi. Stock solutions of the extract residues were prepared by adding $100 \mathrm{ml}$ of the solvents onto the residues and then these stock solutions were sterilized by membrane filtration using $0.45 \mu \mathrm{m}$ pore size filters. From each sterilized solution, certain volumes in $1 \mathrm{ml}$ aliquots were added to 10 sterilized tubes containing 50 sterilized filter paper disks each. If the volume of the stock solution to be added was less than $1 \mathrm{ml}$, its volume was added up to $1 \mathrm{ml}$ with pure solvent before addition. After evaporation of the solvent of the solutions in tubes, solvent free disks with the extract residues were obtained. The residue contents of these disks changed from $1.32 \mathrm{mg} / \mathrm{disk}$ to $2.5 \mu \mathrm{g} /$ disk for the diethyl ether extract, from $2.12 \mathrm{mg} /$ disk to $4.1 \mu \mathrm{g} /$ disk for the acetone extract, from $3.78 \mathrm{mg} /$ disk to $7.3 \mu \mathrm{g} /$ disk for the chloroform extract, from $0.32 \mathrm{mg} /$ disk to $0.63 \mu \mathrm{g} /$ disk for the petroleum ether extract, and from $3.06 \mathrm{mg} / \mathrm{disk}$ to $5.9 \mu \mathrm{g} / \mathrm{disk}$ for the ethanol extract.

After inoculation of $250 \mu \mathrm{l}\left(10^{8}\right.$ cells $/ \mathrm{ml}$ or spores $/ \mathrm{ml}$ ) solutions of the bacteria onto nutrient agar and of the yeasts and filamentous fungi onto potato dextrose agar, an array of the disks containing different amounts of the extract residue from the same extract were transferred into inoculated microorganism media to determine the MIC value of the extract. Chloramphenicol and ketoconazole were used as positive control substances. Pure solvent treated and dried disks were used as negative control disks. The bacterial plates were incubated for $24-48 \mathrm{~h}$ at $35-37^{\circ} \mathrm{C}$ and the fungal plates were incubated for $5 \mathrm{~d}$ at $20-25^{\circ} \mathrm{C}$. The MIC values were determined by checking the inhibition zones formed and all MIC value determination experiments were done twice.

\section{Isolation and characterization of 3-hydroxyphysodic acid}

Having spotted some amount of the residue from five extracts on four silica gel TLC plates (Merck, Silica gel $60 \mathrm{~F}_{254}$ ), they were developed in solvent systems A, B, C, and $\mathrm{G}$ which are employed in the TLC of lichen substances (Orange et al., 2001). The spots belonging to 3-hydroxyphysodic acid on the developed plates were located using the $R_{\mathrm{f}}$ values of 3-hydroxyphysodic acid given in the literature (Orange et al., 2001; Huneck and Yoshimura, 1996). Furthermore Hypogymnia tubulosa is used as a control lichen to test the presence of 3-hydroxyphysodic acid or its determination (Orange et al., 2001). Solvent system A, that appeared to be a suitable solvent system, was used to separate 3-hydroxyphysodic acid from other constituents in the acetone extract of the lichen using the preparative TLC technique. Besides the $R_{\mathrm{f}}$ values, further characterization of 3-hydroxyphysodic acid was done checking its melting point and comparing its IR spectrum with the ones given in the literature (Huneck and Yoshimura, 1996).

\section{Determination of MIC values of \\ 3-hydroxyphysodic acid}

A similar procedure to the one described above for determination of MIC values of the extracts was applied for determination of MIC values of 3-hydroxyphysodic acid against thirteen bacteria and two yeasts. A stock solution of $50 \mathrm{mg}$ of 3-hydroxyphysodic acid in $5 \mathrm{ml}$ acetone was pre- 
pared and subsequently diluted two-fold with acetone ten times. From these solutions, an array of disks whose 3-hydroxyphysodic acid content varied from $0.5 \mathrm{mg} /$ disk to $0.97 \mu \mathrm{g} / \mathrm{disk}$ was prepared and used for determination of MIC values of 3-hydroxyphysodic acid the same way as for determination of MIC values of the extracts.

\section{Results and Discussion}

We tested the antimicrobial activity and determined MIC values of the diethyl ether, petroleum ether, ethanol, chloroform, and acetone extracts of Hypogymnia tubulosa against thirteen bacteria, two yeasts, and ten filamentous fungi as well as those of 3-hydroxyphysodic acid (Fig. 1) against the bacteria and yeasts. The Kirby and Bauer method was used for determination of MIC values of the extracts and 3-hydroxyphysodic acid. We did not observe any antifungal activity of the extracts against all of the tested filamentous fungi and thus we did not pursue to investigate the anti-

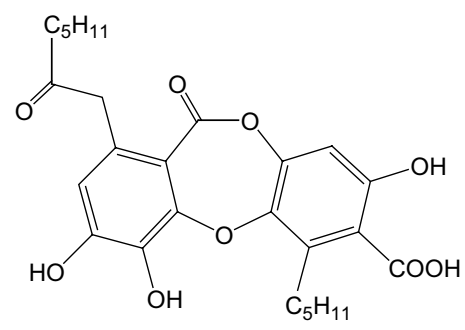

Fig. 1. Chemical structure of 3-hydroxyphysodic acid. fungal activity of 3-hydroxyphysodic acid against them. Furthermore no antimicrobial activity of the extracts and 3-hydroxyphysodic acid against $P$. aeruginosa, $P$. syringae, $Y$. enterocolitica, and C. glabrata was observed, but at least one of the extracts or 3-hydroxyphysodic acid showed activity against the rest of the bacteria namely $A$. hydrophila, B. cereus, B. subtilis, E. coli, K. pneumoniae, L. monocytogenes, P. vulgaris, S. typhimurium, S. aureus, S. faecalis, and C. albicans (Table I). From the points of the number of observed activity and low MIC values, the diethyl ether extract of Hypogymnia tubulosa seemed to be the best among the extracts for determination of antimicrobial activity. It showed activity against nine bacteria and gave MIC values as low as $5.1 \mu \mathrm{g} /$ disk for four of the bacteria (Table I). The petroleum ether and ethanol extracts were active only against five and four bacteria, respectively. These results may be reasonable because of the variation in the polarities of the solvents. A nonpolar petroleum ether and highly polar ethanol may not extract antimicrobial active lichen substances of Hypogymnia tubulosa as efficiently as diethyl ether and chloroform whose polarities are 4.3 and 4.8, respectively. It is also worthwhile to mention that the petroleum ether extract produced very low MIC values, $1.25 \mu \mathrm{g} / \mathrm{disk}$, for $E$. coli, S. typhimurium, and $S$. faecalis.

The 3-hydroxyphysodic acid constituent of $\mathrm{Hy}$ pogymnia tubulosa showed activity against eight bacteria and one yeast (Table I). Its MIC values

Table I. MIC values of the extracts of Hypogymnia tubulosa and its 3-hydroxyphysodic acid constituent.

\begin{tabular}{|c|c|c|c|c|c|c|c|}
\hline \multirow[b]{2}{*}{ Microorganism } & \multirow[b]{2}{*}{$\begin{array}{c}\text { Diethyl } \\
\text { ether } \\
{[\mu \mathrm{g}]}\end{array}$} & \multirow[b]{2}{*}{$\begin{array}{c}\text { Acetone }^{\mathrm{a}} \\
{[\mu \mathrm{g}]}\end{array}$} & \multicolumn{3}{|c|}{ MIC (against $10^{7}$ cells) } & \multicolumn{2}{|c|}{ 3-Hydroxyphysodic acid } \\
\hline & & & $\begin{array}{l}\text { Chloro- } \\
\text { form }^{\mathrm{a}} \\
{[\mu \mathrm{g}]}\end{array}$ & $\begin{array}{c}\text { Petroleum } \\
\text { ether } \\
{[\mu \mathrm{g}]}\end{array}$ & $\begin{array}{c}\text { Ethanol }^{\mathrm{a}} \\
{[\mu \mathrm{g}]}\end{array}$ & $\begin{array}{l}\text { 3-Hydroxy } \\
{[\mu \mathrm{g} / 50 \mu \mathrm{l}]}\end{array}$ & $\begin{array}{l}\text { dic acid } \\
{[\mathrm{mm}]}\end{array}$ \\
\hline Aeromonas hydrophila & 660 & $-{ }^{\mathrm{b}}$ & - & - & - & - & - \\
\hline Bacillus cereus & 330 & 33.1 & 236 & - & 95.6 & 31.3 & 1.28 \\
\hline Bacillus subtilis & - & - & - & - & - & 62.5 & 2.57 \\
\hline Escherichia coli & 20.6 & 530 & 29.5 & 1.25 & - & 15.6 & 0.64 \\
\hline Klebsiella pneumoniae & 5.15 & - & - & - & - & - & - \\
\hline Listeria monocytogenes & 330 & 33.1 & 945 & 80.0 & 47.8 & 1.95 & 0.08 \\
\hline Proteus vulgaris & 5.15 & 265 & 945 & 320 & 95.6 & 31.3 & 1.28 \\
\hline Staphylococcus aureus & 165 & 66.3 & 118 & - & - & 31.3 & 1.28 \\
\hline Streptococcus faecalis & 5.15 & 132.5 & 945 & 1.25 & 95.6 & 1.95 & 0.08 \\
\hline Salmonella typhimurium & 5.15 & - & 3780 & 1.25 & - & 1.95 & 0.08 \\
\hline Candida albicans & - & - & - & - & - & 1.95 & 0.08 \\
\hline
\end{tabular}

a The concentrations of the stock solutions were $2.60 \mathrm{mg} / \mathrm{ml}$ for the diethyl ether extract, $4.17 \mathrm{mg} / \mathrm{ml}$ for the acetone extract, $7.41 \mathrm{mg} / \mathrm{ml}$ for the chloroform extract, $0.63 \mathrm{mg} / \mathrm{ml}$ for the petroleum ether extract, and $5.99 \mathrm{mg} / \mathrm{ml}$ for the ethanol extract.

b -: Inactive. 
against L. monocytogenes, S. typhimurium, S. faecalis, and $C$. albicans were remarkably low and determined as $1.95 \mu \mathrm{g} /$ disk. To the best of our knowledge, no information about the antimicrobial activity of 3-hydroxyphysodic acid is available for the last decade in the literature. In our previous antimicrobial activity studies, we investigated the antimicrobial activities of lichen compounds (+)-usnic acid, (-)-usnic acid, norstictic acid, atranorin, protocetraric acid, and fumarprotocetraric acid (Y1lmaz et al., 2004; Tay et al., 2004). If we compare the antimicrobial activity of 3-hydroxy-

Huneck S. (1999), The significance of lichens and their metabolites. Naturwissenschaften 86, 559-570.

Huneck S. (2001), New results on the chemistry of lichen substances. In: Progress in the Chemistry of Organic Natural Products, 81 (Herz W., Falk H., Kirby G. W., and Moore R. E., eds.). Springer, Wien, New York, pp. 224-230.

Huneck S., and Yoshimura I. (1996), Identification of Lichen Substances. Springer, Berlin.

National Committee for Clinical Laboratory Standards (1993), Approved Standard M2-A5. Performance Standards for Antimicrobial Disk Susceptibility Tests. National Committee for Clinical Laboratory Standards, Villanova, Pennsylvania.

Orange A., James P. W., and White F. J. (2001), Microchemical Methods for the Identification of Lichens. British Lichen Society, London. physodic acid to theirs, none of the above compounds showed activity against $E$. coli and $S$. typhimurium whereas 3-hydroxyphysodic acid did.

This study makes a contribution to the literature and gives encouragement to pursue biologically active compounds from lichens.

\section{Acknowledgement}

We thank the Anadolu University Research Fund for grant AÜ 041007 in support of this research.

Tay T., Özdemir Türk A., Yılmaz M., Türk H., and Kivanç M. (2004), Evaluation of the antimicrobial activity of the acetone extract of the lichen Ramalina farinacea and its (+)-usnic acid, norstictic acid, and protocetraric acid constituents. Z. Naturforsch. 59c, $384-388$.

Toma N., Ghetea L., Nitu R., and Corol D. I. (2001), Progress and perspectives in the biotechnology of lichens. Roum. Biotechnol. Lett. 6, 1-15.

Yılmaz M., Özdemir Türk A., Tay T., and Kıvanç M. (2004), The antimicrobial activity of the lichen Cladonia foliacea and its (-)-usnic acid, atranorin, and fumarprotocetraric acid constituents. Z. Naturforsch. 59c, 249-254. 